\title{
PENDEKATAN BARU TERAPI KANKER
}

Oleh: Sugiharto

Dosen Jurusan Pendidikan Olahraga FIK UNES

\section{Abstrak}

Penyakit kanker merupakan suatu penyakit degeneratif yang sering menyebabkan kematian apabila tidak mendapat perawatan dengan baik. Terapi kanker yang saat ini dilakukan adalah pembedahan, radioterapi dan kemoterapi. Terapi tersebut bila dilakukan sendiri atau bersama-sama, kira-kira dapat menyembuhkan setengah dari penderita kanker. Hal ini berarti terapi tersebut belum memberikan hasil yang memuaskan, oleh karena itu dicoba berbagai macam pendekatan baru terapi kanker.

Tiga target molekuler baru yang saat ini merupakan target dari pengobatan penyakit kanker adalah onkogen, tumor suppressor genes, serta gen pengatur replikasi DNA dan DNA repair. Obat genetik baru yang dipakai untuk terapi kanker adalah antisense agent dan triples agent. Terapi gen untuk kanker dapat dilakukan secara ex vivo dan in vivo. Terapi gen ex vivo dilakukan dengan cara modefikasi genetik sel tumor, modifikasi genetik fibroblas, dan transfer gen kepada tumor-infiltrating bymphocytes (TIL). Terapi gen in vivo dilakukan dengan cara meningkatkan imunogenesitas sel tumor atau menginsersikan suicide genes pada sel tumor.

Pendekatan baru terapi kanker juga dilakukan dengan kombinasi terapi gen dan terapi radiasi, onkolisis dengan perantaraan virus atau dengan cara merusak pembuluh darah 
tumor yang dibutuhkan untuk pertumbuhan dan penyebaran tumor. Dengan adanya pendekatan baru dalam terapi kanker, diharapkan dapat dilakukan pengobatan penderita penyakit kanker dengan hasil yang lebih baik serta tidak menimbulkan efek samping yang berarti bagi penderita.

Kata kunci : kanker, terapi.

Sejauh ini penanganan neoplasma ganas atau kanker masih memiliki banyak kendala. Berbagai problem masih memerlukan pemecahan. Problem dapat terjadi sebagai akibat keterbatasan medik dan penderita, yang pada hakikatnya merupakan sumber problema di klinik. Problem juga dapat ditimbulkan oleh sifat-sifat sel kanker sebagai akibat perubahan yang terjadi dan tidak kalah pentingnya bagaimana cara mengidentifikasi serta mengatasi untuk terapinya. Problem terakhir ini, tidak saja merupakan problema yang mengasyikkan untuk diteliti, namun juga merupakan sumber penyebab gagalnya pengobatan kanker.

Seperti telah diketahui bersama bahwa sampai saat ini terapi kanker yang biasa dilakukan adalah kemoterapi, radiasi, dan pembedahan. Terapi tersebut jika dilaksanakan sendiri atau bersama-sama, mungkin dapat menyembuhkan setengah dari penderita kanker. Oleh karena cukup tingginya angka kejadian penyakit kanker, angka kematian yang terjadi pada penderita kanker yang diterapi melalui tiga cara terapi tersebut di atas masih cukup tinggi. Penyakit kanker terjadi pada satu dari empat orang. Satu dari enam orang di Amerika Serikat dan Eropa meninggal disebabkan kanker (Rosenberg, 1990).

Hasil kemoterapi yang dilaksanakan saat ini, kadang-kadang hanya memperlambat kematian, namun jarang dapat menyembuhkan penderita kanker secara keseluruhan. Obat kemoterapeutik dirancang untuk merusak sel neoplastik karena mengalami proliferasi berlebihan. Sasaran obat tersebut adalah sintesis DNA atau mitosis. Problem dari cara pendekatan dengan obat kemoterapeutik ini adalah proliferasi tidak terjadi pada sel kanker saja, namun sel normal seperti sel hematopoietik dan sel epitel juga berproliferasi untuk mempertahankan integritas jaringan ini. Akibat dari obat kemoterapeutik yang digunakan saat ini menimbulkan efek samping yang kurang memuaskan dan berbahaya bagi penderita (Oliff, Gibbs, dan McCormick, 1996; Moolten, 1997).

MEDIKORA Vol. II, No. 1, April 2006: 39-56. 
Radioterapi dalam pengobatan penyakit kanker juga masih memiliki keterbatasan, sebab dibatasi oleh toksisitas radiasi pada sel normal dan resistensi dari banyak jenis keganasan terhadap dosis radiasi konvensional (Stackhouse, Rogers, dan Buchsbaum, 1999).

Terapi konvensional yang digunakan untuk pengobatan penyakit kanker, sampai saat ini belum memberikan hasil yang memuaskan, maka perlu cara pendekatan baru dalam pengobatan penyakit kanker agar dapat menyembuhkan penyakit tanpa menimbulkan efek samping yang kurang memuaskan dan tidak berbahaya bagi penderita.

\section{BATASAN}

Dalam uraian berikut perlu diadakan pembatasan agar seandainya ada perbedaan pemahaman, memang semata-mata perbedaan konsep pendekatan yang digunakan.

\section{Sel Kanker}

Sel kanker adalah sel yang berubah bentuk dan fungsinya sedemikian rupa sehingga sel tersebut mengalami peningkatan jumlah yang abnormal, invasi, penyebaran melalui pembuluh getah bening dan pembuluh darah, serta dapat menimbulkan metastasis di kelenjar getah bening regional atau organ yang jauh.

\section{Kemoprevensi}

Kemoprevensi adalah penggunaan obat alamiah untuk menghambat pertumbuhan kanker invasif melalui hambatan kerusakan DNA. Dengan demikian penggunaan obat ini menghambat karsinogenesis atau menghilangkan proses berlanjutnya sel-sel premaligna yang telah rusak .

\section{Imunoterapi}

Imunoterapi atau terapi vaksin adalah suatu usaha terapi terhadap kanker melalui reaksi sistem imun yang secara teori dapat mengeliminasi semua sel kanker walaupun sel tersebut telah mengalami metastasis atau muncul kembali setelah beberapa tahun kemudian.

\section{Terapi Gen}

Terapi gen adalah suatu metode pengobatan dengan cara memasukan gen asing ke dalam sel target yang memiliki gen cacat. 


\section{KEJADIAN KANKER DAN PENYEBARANNYA}

Dalam usaha memperoleh pendekatan yang tepat dan efektif dalam pengobatan kanker, para ilmuwan telah mengeksplorasi sifat-sifat kanker terutama bagaimana kejadian kanker dan penyebarannya. Akhir-akhir ini kecacatan molekuler yang mentransformasikan sel-sel normal menjadi sel malignant telah menjadi jelas. Sebagian besar tumor disebabkan mutasi satu atau lebih dari tiga jenis gen yaitu proto-oncogen, tumor suppresor gen, dan DNA repair gen (Oliff, Gibbs, dan McCormick, 1996).

Proto-oncogen adalah gen normal yang menyandi faktor pertumbuhan atau protein yang berperan dalam transduksi sinyal. Onkogen adalah versi mutan proto-onkogen yang merangsang pertumbuhan sel melewati siklus sel. Gen inilah yang menyebabkan kanker yaitu proliferasi yang tidak terkendalikan dari satu jenis sel. Tumor suppresor gen merupakan gen yang mencegah pertumbuhan kanker, banyak kanker terjadi karena tidak berfungsinya protein pengatur kunci yang dikode oleh gen ini. DNA repair gen adalah gen yang mengontrol dan memelihara keutuhan DNA, yang sering mengalami kerusakan selama replikasi. Tanpa mekanisme ini, gen yang rusak akan diturunkan pada anak sel sebagai mutasi permanen. Sel-sel tumor sering mengalami kecacatan dalam proses perbaikan DNA.

Penyebaran kanker sebagian besar tidak diturunkan, namun sebagai akibat mutasi yang didapat karena faktor eksternal seperti asap tembakau atau dosis radiasi yang tinggi. Mutasi yang lama ini terakumulasi dalam sel dan akhirnya mengubah sel menjadi tidak mampu mengontrol pertumbuhannya sendiri, suatu ketidakmapuan yang cenderung menimbulkan kanker (Blaese, 1997).

Sel-sel tumor dapat merangsang angiogenesis atau neovascularisasi merupakan prolifirasi kapiler baru yang tidak terjadi dalam keadaan normal kecuali saat menstruasi atau terjadi kerusakan jaringan. Neofaskularisasi merupakan salah satu tahap penting transisi tumor dari kelompok sel-sel mutan yang kecil, tidak berbahaya, menjadi besar, menjadi ganas dan dapat menyebar ke organ lain di seluruh tubuh. Apabila sel yang sehat menjadi kanker dan mulai membelah dengan cepat, sel-sel anakan yang dihasilkan bergabung menjadi suatu massa yang memiliki ukuran mikroskopik. Ketika sel tersebut menumpuk, ia semakin menjauh dari kapiler yang terdekat. Jika berjuta-juta sel demikian terakumulasi, tumor kecil atau in situ carcinoma berhenti meluas dan mencapai suatu keadaan stabil, jumlah sel yang mati seimbang dengan sel yang berproliferasi. Sesudah

MEDIKORA Vol. II, No. 1, April 2006: 39 - 56. 
beberapa bulan atau beberapa tahun dalam keadaan stabil, in citu carcinoma secara spontan dapat merangsang pertumbuhan kapiler baru dan mulai menyerang jaringan di sekitarnya (Folkman, 1996).

\section{PENDEKATAN MOLEKULER TERAPI KANKER}

Atas dasar sebab terjadinya kanker, target terapi melalui pendekatan molekuler terdiri dari tiga kelompok gen, yaitu: (1) ongkogen yang berfungsi merangsang progresi siklus sel, urutan kejadian sel mengalami pembesaran, replikasi DNA, dan membelah dengan meneruskan rangkaian gen yang lengkap kepada sel anak; (2) tumor supresor gen, yaitu sekelompok gen yang membatasi perkembangan sel; dan (3) gen yang mengatur replikasi dan perbaikan DNA.

\section{Onkogen yang Mengaktivasi Kanker}

Onkogen adalah bentuk mutan dari gen normal yang disebut protozonkogen yang berfungsi mendorong perkembangan sel. Protein mutan yang dihasilkan oleh onkogen mungkin hanya berbeda satu asam amino jika dibandingkan protein normal, namun perubahan satu asam amino saja secara radikal dapat mengubah fungsi protein. Pada umumnya kanker disebabkan oleh mutasi pada gen ras. Protein yang disandi oleh gen ras berfungsi sebagai relay switch dalam penerusan sinyal yang mengakibatkan sel membelah dalam berespons terhadap rangsangan dari luar. Mutasi pada gen ras mengakibatkan protein tersebut terus menerus memberi informasi yang keliru pada sel yaitu memerintahkan sel untuk membelah tanpa henti. Ini menunjukkan bahwa komponen yang dapat menghambat aktivasi protein ras mutan dapat menjadi agent antikanker yang efektif (Oliff, Gibbs, dan McCormick, 1996).

Protein ras awal mula dibentuk sebagai prekursor inaktif. Maturasinya terjadi melewati tiga tahap, yaitu farnesilasi, proteolisis, dan methilasi, di empat yang disebut kotak CAAX. Tahap farnesilasi merupakan tahap terpenting, 15 atom karbon ditambahkan pada prekursor melewati reaksi yang dikatalisis enzim farnesyl transferase. Ras yang mature dapat berinteraksi dengan protein lain dan merangsang perkembangan sel. Obat-obat yang menghambat reaksi farnesilasi berarti mencegah aktifnya protein ras dan mencegah perkembangan sel-sel tumor.

Onkogen lain yang dapat digunakan sebagai target terapi kanker adalah gen yang menyandi enzim protein kinase. Sel normal protein kinase membantu 
mengatur sinyal antara membran sel dan nukleus, memulai progresi sel untuk masuk siklus sel dan mengendalikan berbagai fungsi metabolisme sel. Protein kinase dapat menimbulkan kanker melalui du cara, yaitu: (1) produksi yang berlebihan dari protein kinase, disebabkan oleh mutasi di daerah pengontrolan gen. Produksi kinase yang berlebihan ini menyebabkan sel tetap membelah walaupun seharusnya dia berhenti membelah. Kinase dalam jumlah besar pada sel kanker adalah reseptor untuk epidermal growth factor (EGF); (2) struktur yang abnormal, sehingga merangsang sel untuk membelah terus menerus. Beberapa protein kinase abnormal pada kanker manusia adalah Abl, Src, dan cyclin dependent kinase. Pada hewan telah didapatkan beberapa agent penghambat perkembangan sel kanker yang memiliki gen protein kinase yang mengalami mutasi. Suatu tanda atau harapan bahwa mungkin obat-obat antagonis protein kinase dapat bekerja dalam tubuh manusia.

\section{Tumor Supresor Gen}

Banyak kanker disebabkan oleh tidak berfungsinya protein pengatur yang disandi oleh gen supresor. Dua protein supresor tumor yang utama adalah pRB (berasal dari retinoblastoma) dan p53. Protein pRB membantu mengendalikan siklus sel khusunya berfungsi sebagai rem terhadap replikasi DNA. Mutasi pada protein ini membuat protein kinase tidak aktif sehingga pembelahan sel berjalan terus. Di sisi lain, p53 memerintahkan sel untuk bunuh diri jika DNA mengalami kerusakan, misalnya akibat obat-obatan atau radiasi. Apabila p53 abnormal, replikasi sel yang memiliki DNA yang rusak tidak dicegah. Salah satu cara menghadapi sel-sel tumor adalah melewati virus yang secara genetik dirancang agar memproduksi sel dengan p53 abnormal namun tidak di sel-sel yang sehat. Prinsipnya, virus dapat bergerak secara tidak terkontrol hanya di seluruh sel-sel tumor dan membunuhnya, namun pendekatan ini mengalami beberapa kesukaran, virus akan dimusnahkan oleh sistem immun sebelum mencapai sel

\section{Gen yang Mengatur Replikasi dan Perbaikan DNA.}

Ketika replikasi, gen yang mengecek dan mempertahankan integritas DNA bisa mengalami kerusakan. Kemungkinan untuk memperbaiki gen yang rusak akan menurun sekali, sehingga gen yang rusak diteruskan ke sel anaknya sebagai mutasi yang permanen. Sel-sel tumor sering mengalami

MEDIKORA Vol. II, No. 1, April 2006: 39 - 56. 
cacat dalam proses perbaikan DNA. Ketika kanker colon manusia, mutasi terjadi pada gen-gen yang membantu perbaikan DNA yaitu MLH1, MSH2, PMS1 dan PMS2. Gen lain berperan tidak langsung dalam perbaikan DNA yaitu menyandi protein check point yang mengamati perkembangan sel lewat siklus sel dan mencegah tahap berikutnya bila tahap sebelumnya tidak sempurna, misal DNA yang dicopy secara tepat. Protein check point yang banyak dikenal adalah protein ATM dan protein p53 (serba guna). Sel-sel tumor yang kehilangan gen ATM dan p53 normal kehilangan mekanisme checking DNA. Akibat DNA rusak akan mengalami proses replikasi, sehingga meningkatkan frekuensi mutasi acak pada sel anak (Oliff, Gibbs, dan McCormick, 1996).

Selain target dalam pertumbuhan sel, terapi molekuler juga ditujukan untuk molekul penting lainnya, seperti protein yang menjaga sel agar tetap pada satu tempat dalam tubuh. Para peneliti telah mendapatkan obat yang menghambat metastasis sel-sel kanker, seperti inbibitor protease. Obat lain mencoba menghilangkan kemampuan tolemerase, enzim yang membentuk kembali ujung kromosom yang bereplikasi dan memungkinkan sel kanker tetap immortal, sementara sel-sel lain mati. Komponen seperti TNP-470 kemungkinan dapat mematikan pembentukan pembuluh darah baru yang memberi makan tumor (Oliff, Gibbs, dan McCormick, 1996).

\section{STRATEGI ANTISEN AGENT DAN TRIPLEX AGENT}

Penelitian untuk menemukan obat yang menghambat protein berhubungan dengan terjadinya penyakit terus berjalan. Akhir-akhir ini peneliti mencari target yang lain, yaitu asam nukleat (DNA dan RNA). Peneliti berusaha menemukan obat yang dapat berikatan dengan asam nukleat yang terlibat dalam sintesis protein yang berhubungan dengan terjadinya penyakit. Obat tersebut adalah untai dari DNA sintetis yang disebut antisense agent dan triplex agent. Obat ini secara potensial dapat menyerang sel kanker dengan tidak membahayakan sel lain (Cohen dan Hogan, 1994).

\section{Antisense agent}

Berdasarkan adanya agent yang dapat bergabung dengan active site protein yang terlibat dalam penyakit, dikembangkan dua strategi untuk menghambat 
produksi protein yang berhubungan dengan penyakit. Stategi tersebut antisen, obat-obat baru diharapkan berikatan dengan mRNA sehingga menghalangi transkripsi atau tranlasi gen-gen terpilih, dan triplex, jika obat-obat baru berikatan dengan segmen DNA terpilih. Setiap sintesis protein, gen yang memiliki komposisi khusus harus ditrankripsikan dari DNA menjadi molekul mRNA, dan mRNA tersebut harus ditranslasikan menjadi salinan protein. Strategi antisen bertujuan untuk menghalangi translasi secara selektif. Oligonukleotida antisen menghentikan translasi dengan dua metode yaitu dengan mengganggu kemampuan sel untuk membaca RNA sens dan berikatan dengan mRNA, menstimulasi enzim ribonuclease $\mathrm{H}$ memecah dan menghancurkan ikatan mRNA tersebut. Strategi triplex bertujuan untuk menghentikan produksi protein yang tidak diinginkan secara selektif dengan menghambat transkripsi gennya.

Molekul antisen yang merupakan oligonukleotida dapat dirancang untuk berfungsi sebagai obat dan dikirim ke sel dalam tubuh secara mudah dan efisien. Masalahnya oligonukleotida mengandung muatan negatif di setiap fosfatnya. Molekul yang bermuatan sering mengalami kesulitan dalam menembus membran sel yang tidak bermuatan. Selain itu sel memiliki enzim yang akan memecah DNA asing, jadi iligomer yang dapat masuk ke sel akan dipecah oleh enzim di sel. Untuk mengatasi permasalahan tersebut, dilakukan modifikasi dari oligonukleotida standar. Usaha tersebut adalah mengubah satu atom oksigen dari setiap gugus fosfat diganti gugus metil $\left(\mathrm{CH}_{3}\right)$. Dengan penggantian ini gugus fosfat yang bermuatan negatif diganti dengan gugus metilfosfonat yang tidak bermuatan. Hal ini akan meningkatkan pemasukan oligonukleotida ke sel dan membuat oligonukleotida menjadi resisten terhadap proses degradasi enzim di sel. Hilangnya muatan negatif menjadikan oligonukleotida menjadi hidrofobik, sehingga menjadi tidak larut dalam air. Senyawa yang tidak larut dalam air ini sukar dibuat dalam jumlah besar (Cohen dan Hogan, 1994).

Pilihan selanjutnya adalah mengganti satu atom oksigen pada gugus fosfat dengan atom sulfur yang bermuatan negatif untuk dibuat oligonukleotida metilsulfonat. Oligomer fosfotionat ini lebih dikenal sebagai S-ologis, yang larut dalam air sehingga lebih mudah dibuat dan resisten terhadap enzim pemecah nukleotida asing di sel. Oligonukleotida yang

MEDIKORA Vol. II, No. 1, April 2006: 39- 56. 
bermuatan negatif tidak hanya masuk sel dengan cara defusi langsung melewati membran sel, namun juga melewati endositosis. Dalam proses endositosis membran sel menelan senyawa tesebut dan memasukkan ke vesikel. Yang menjadi pertanyaan apakah bahan tersebut siap dilepas ke sitoplasma? (Cohen dan Hogan, 1994).

Untuk merancang obat-obat antisen, panjang oligomer minimal 15 nukleotida agar dapat berikatan kuat dengan mRNA target, dan terhindar dari ikatan mRNA nontarget. Saat ini sedang diteliti penggunaan oligonukleotida antisense dalam pengobatan chronic myelogenous leukemia. Penelitian tersebut meneliti kemampuan oligonukleotida antisense dalam mengeliminasi sel kanker selama pembersihan sumsum tulang secara ex vivo. Target dalam pengobatan tersebut adalah mRNA yang ditranskripsi dari gen $c-m y b$. Pada keadaan normal gen $c-m y b$ memacu proliferasi normal dari sel darah. Gangguan gen tersebut merupakan penyebab leukumia pada manusia (Cohen dan Hogan, 1994).

\section{Pembentukan untaian triplex}

Di bawah kondisi tertentu, gen alami yang mengandung banyak pasangan basa AT dan GC dapat berikatan dengan suatu oligonukleotida yang dirancang untuk membentuk triplex TAT dan $\mathrm{C}^{+} \mathrm{GC}$. Triplex $\mathrm{C}^{+} \mathrm{GC}$ adalah triplex belix hanya dapat terbentuk oleh untaian nukleotida sitosin dengan double belix GC dalam larutan sedikit asam yang banyak mengandung proton. Oligonukleotida pembentuk triplex tidak mengganggu ikatan hidrogen pada DNA untai ganda asalnya. Setiap basa oligonukleotida membentuk dua ikatan hidrogen baru dengan basa purin pada daerah target dari dupleks DNA. Sebagian oligonukleotida berorientasi paralel dan sebagian berorientasi antiparalel terhadap targetnya. Rantai DNA bersifat asmitrik, satu ujung disebut sebagai ujung 5' dan ujung yang lain disebut ujung 3'. Dalam DNA untai yang klasik, rantai DNA berorientasi antiparalel, yaitu ujung 5' berpasangan dengan ujung 3' dari rantai yang lain. Oligonukleotida yang terdiri atas sitosin dan timin, cenderung membentuk orientasi paralel terhadap rantai yang kaya purin dari target DNA dupleks. Oligonukleotida yang mendandung guanin dan timin cenderung berorientasi antiparalel. Jika hal ini diperhatikan, suatu oligonukleotida akan gagal dalam mengenal target DNA (Cohen dan Hogan, 1994). 
Fakta terakhir menunjukkan bahwa triplex agent yang mempunyai target pada daerah penyandi dari suatu gen dapat menghambat aktivitas RNA polimerase dalam membentuk transkripsi mRNA. Penelitian ini menunjukkan bahwa apabila inisiasi dari transkripsi tidak dapat dicegah, triplex agent dapat menghentikan transkripsi pada daerah penyandi.

Beberapa hambatan yang dihadapi dalam strategi triplex ini adalah oligonukleotida yang diatur untuk menghentikan transkripsi dalam sel dapat bekerja apabila dikirim dengan konsentrasi yang tinggi, selain itu target betulbetul mengandung semua basa purin pada untaian yang sama (Cohen dan Hogan, 1994).

Strategi antisense agent dan triplex agent saat ini masih jauh dari sempurna. Apabila terapi ini dapat berkembang dengan pesat, diharapkan obat tersebut kelak dapat dipakai sebagai salah satu cara dalam pengobatan penyakit kanker.

\section{IMUNOTERAPI KANKER}

Sistem imun telah diketahui sejak lama dapat menyerang kanker. Sel tumor cukup berbeda dengan sel normal, sehingga sistem imun dapat mengenal dan merusak sel kanker. Kanker pada manusia acapkali mengalami regresi spontan, yang ditimbulkan oleh respons imun yang merusak sel kanker, namun yang seringkali terjadi adalah immune survillance gagal mengeliminasi sel kanker, sehingga sel kanker akan berkembang terus dan membentuk tumor yang mengancam kehidupan manusia (Rosenberg, 1990; Williams, 1996).

Kerja respons imun melibatkan berbagai tipe sel yang berbeda, yaitu limfosit, monosit, makrofag, eosinofil, dan basofil, sebagai komando dari selsel tesebut adalah limfosit. Ada dua subklas limfosit yaitu sel B dan sel T. Kedua sel inilah yang bertanggung jawab terhadap spesifikasi respons imun. Sel T terdiri dari sel T helper, sel T supresor, yang memodulasi respons imun, dan sel T sitotoksik yang membunuh sel abnormal secara langsung.

\section{Aktivasi sel $T$}

Sel $\mathrm{T}$ adalah salah satu jenis sel imun yang mengarahkan penyerangan sistem imun terhadap sel kanker. Aktivasi sel T membutuhkan dua sinyal yaitu suatu antigen khusus yang dipaparkan molekul permukaan yang disebut antigen presenting cells (APC) dan protein B7. Tanpa protein B7, sel T menjadi

MEDIKORA Vol. II, No. 1, April 2006: 39-56. 
tidak responsif biarpun tumor membawa antigen yang menimbulkan respons imun, namun biasanya sel tumor tidak mempunyai protein B7, sehingga tidak dapat membangkitkan respons imun yang merusak sel tumor tersebut (Williams, 1996).

Sel T memiliki dua reseptor yang dapat berikatan dengan molekul B7 yaitu CD28 dan CTLA-4. Jika molekul B7 berikatan dengan CD28, sel T menjadi aktif, hal ini menunjukkan bahwa sel $\mathrm{T}$ telah menerima sinyal antigen khusus. Jika B7 berikatan dengan CTLA-4, sel T menjadi penghambat terhadap aktivasi yang membatasi respons imun. Pemberian antibodi yang berikatan dengan CTLA-4 pada sel-sel tumor mencit, menghambat interaksinya dengan B7 dan meningkatkan respons anti tumor hewan tersebut (Williams, 1996).

\section{Transfer Sel Lymphokyne-Activated Killer (LAK) dan Interleukin-2}

Sel-sel sistem imun sering mengontrol aktivitas satu sama lainnya dengan mensekresi sejumlah kecil hormon potensial yang disebut sitokin. Sel T helper juga memproduksi sitokin yang dikenal dengan interleukin-2 (IL2), yang awalnya disebut faktor pertumbuhan sel T. IL-2 ini menyebabkan sel $\mathrm{T}$ helper dan sel $\mathrm{T}$ sitotoksik yang dirangsang antigen bereplikasi. Jika sel-sel tumor dibiakkan dengan IL-2, maka IL-2 tidak saja menimbulkan limfosit bereplikasi, tetapi juga merangsang limfosik untuk mengenal dan membunuh sel kanker. Pemberian IL-2 pada limfosit yang berasal dari darah orang yang sehat juga memungkinkan limfosit tersebut membunuh berbagai sel kanker manusia secara in vitro. Sel-sel yang teraktivasi ini kemudian disebut sel bymphokyne-avtivated killer (LAK) dan tidak membahayakan sel-sel normal, sehingga sel LAK ini digunakan untuk senjata anti kanker. Hasil pengobatan kanker stadium lanjut dengan menggunakan kombinasi sel LAK dengan IL2 atau IL-2 saja pada mencit dan manusia menunjukkan bahwa terapi kombinasi pada mencit lebih efektif jika dibandingkan IL-2 saja, untuk manusia dalam membuat kesimpulan yang sama masih memerlukan data yang lebih banyak.

\section{Transfer Sel Tumor Iinfiltrating Lymphocytes (TIL)}

Diduga bahwa apabila sistem imun dibangkitkan terhadap suatu kanker, tumor akan merupakan tempat yang paling banyak mengandung 
limfosit yang peka terhadap sel kanker. Oleh karena itu, dirancang suatu metode baru untuk isolasi limfosit pada tumor. Salah satu metode yang dikembangkan adalah mengambil suatu tumor kecil dari binatang. Tumor tersebut dicerna secara enzimatik untuk memisahkan sel satu dengan sel lainnya, selanjutnya sel dibiakkan dengan IL-2 selama beberapa minggu. Tumor infiltrating lymphocytes (TIL), yaitu lomfosit yang terdapat pada tumor akan berkembang biak di bawah pengaruh IL-2. LAK cells, biasanya akan berhenti berprolifirasi setelah 10 hari, namun limfosit lain yang mampu membunuh sel tumor tetap tumbuh dan bahkan mengganti tumor dengan kumpulan sel. Sel tesebut adalah: tumor infiltrating bymphocytes (TIL). Tidak seperti $L A K$ cells, tumor infiltrating lymphocytes (TIL) seringkali hanya membunuh sel tumor tempat dia berasal, dan tidak membunuh sel tumor yang lain. apabila TIL disuntikkan kepada mencit, TIL mempunyai efektivitas 30 sampai 100 kali lebih besar dari $L A K$ cells dalam menyebabkan regresi tumor yang telah ada, di samping itu TIL juga lebih efektif dalam mengeliminasi kanker yang telah menyebar, apabila dibandingkan dengan LAK cells (Rosenberg, 1990).

\section{Imunisasi Preventif}

Imunoterapi gen ini menggunakan antigen dan antibodi. Vaksin kanker yang menggunakan antigen dilakukan dengan menyuntikkan langsung fragment DNA yang menyandi antigen asing ke sel otot. Ini akan merangsang respons imun yang potensial terhadap antigen tersebut, sebab fragment antigen asing yang memasuki sel otot menyebabkan produksi protein asing yang disandi oleh gen tersebut. Selanjutnya protein ini dikenali oleh limfosit B dan $\mathrm{T}$ yang mengakibatkan sel $\mathrm{B}$ dan $\mathrm{T}$ yang sudah mengalami sensitisasi menyebar ke seluruh tubuh dan siap menyerang sel kanker yang mengandung antigen yang telah mengaktifkan sel tersebut.

Dewasa ini para ilmuwan berusahan membuat antibodi terhadap antibodi yang ada di membran sel kanker. Antibodi adalah produk gen, mereka sudah berhasil membuat vaksin DNA anti-iditipe termasuk DNA penyandi masker kanker. Untaian DNA ini disambung gen yang menyandi sitokin GM-CSF. Walaupun penelitian ini baru dikerjakan pada hewan percobaan namun menunjukkan gejala yang baik.

Terapi gen lain yaitu menggabungkan antibodi anti-tumor dari mencit dengan kemampuan membunuh sel T manusia, dengan menggunakan teknik

MEDIKORA Vol. II, No. 1, April 2006: 39 - 56. 
DNA rekombinan. Penggabungan sel antibodi anti-kanker dari mencit digabung dengan gen yang menyandi reseptor yang dipakai sel $\mathrm{T}$ killer untuk mengenal targetnya. Gen reseptor yang sudah dimodifikasi akan membuat membuat sel $\mathrm{T}$ killer yang belum mengenal sel kanker dapa mengenal sel kanker seperti antibodi mencit. Dalam tabung percobaan sel T ini membunuh sel kanker secara efektif, namun percobaan untuk pengobatan penderita kanker sdang dilakukan (Blaese, 1997).

\section{TERAPI GEN UNTUK KANKER}

Pada awalnya terapi gen dikonseptualisasikan sebagai alat atau sarana mengkoreksi penyakit genetik, khususnya penyakit yang diturunkan dalam bentuk resesif autosomal dan menyebabkan mortalitas yang signifikan. Dengan semakin berkembangnya bioteknologi terapi gen sudah merupakan terapi yang banyak digunakan untuk pengobatan penyakit terutama kenker yang disebabkan mutasi gen.

Terapi gen adalah suatu metode pengobatan dengan cara memasukan gen asing ke dalam sel target yang memiliki gen cacat. Terapi gen secara umum mengirimkan beberapa instruksi dalam bentuk rangkaian DNA ke sel-sel yang berpenyakit, sehingga akan menghasilkan protein terapeutik. Ada tiga tujuan penerapan terapi gen, yaitu: (1) memperbaiki fungsi normal sel atau jaringan; (2) memperbaiki kerusakan gen, dan (3) menambah fungsi baru ke dalam sel. Terapi ini sangat memungkinkan dilakukan, karena virus, bakteri, tumbuhan dan manusia memiliki kode genetik yang sama.

Terapi gen pada kanker dapat dilakukan dengan dua metode yaitu metode ex vivo dan metode in vivo.

\section{Metode Ex Vivo}

Metode ex vivo, yaitu sel yang mempunyai gen cacat diisolasi dari penderita kemudian dilakukan perbaikan gen secara in vitro dengan menggunakan transfer gen atau vektor. Setelah diperbaiki kemudian sel tersebut dikembalikan pada penderita yang bersangkutan. Ada beberapa cara terapi gen secara ex vivo yang akan dibahas untuk penderita kanker, antara lain: 


\section{a. Modifikasi Genetik Sel Tumor}

Terapi gen yang menjadi salah satu strategi terapi kanker yang saat ini banyak diteliti melibatkan modifikasi sel kanker penderita dengan gen yang menyandi sitokin. Pertama-tama sel tumor dari penderita dikeluarkan, kemudian sel tumor tersebut diberi gen yang menyandi sitokin, seperti IL-2, aktivator sel dendritik yang disebut granulocytemacrophage colony strimuating factor (GM-CSF), tumor necrosis factor a (TNFa), interferon-g $(1 \mathrm{HN}-\mathrm{g})$. Kemudian, sel tesebut dimasukkan ke kulit atau otot penderita, selanjutnya dia akan mengeluarkan sitosin yang dapat mengaktifkan sel imun. Secara teori, sel yang genetiknya telah diubah akan menimbulkan aktivasi sel imun di tempat dia disuntikkan. Di samping itu, sel imun yang sekarang menjadi aktif dan dapat mengenal sel kanker, dapat mengalami sirkulasi ke seluruh tubuh dan menyerang tumor yang berada di tempat lain (Strachan dan Read, 1996; Blease, 1997).

Gen-gen lain seperti gen antigen HLA asing telah ditransfer pada tumor. Penyisipan gen yang menyandi HLA-B7 ke dalam tumor pasien yang tidak memiliki HLA-B7 cenderung merangsang respons imun terhadap tumor, sebagai konsekuensi adanya antigen HLA-B7 asing secara selektif di permukaan sel tumor. Respons demikian diharapkan menyediakan imunitas melawan tipe tumor yang sama meskipun tidak ada antigen HLA-B7 asing (Strachan dan Read, 1996; Blease, 1997).

\section{b. Modifikasi Genetik Fibrobls}

Fibroblas merupakan alternatif yang baik untuk pembiakan sel dalam waktu lama, untuk digunakan sebagai target pada beberapa kasus.Trensfer gen yang menyandi sitokinIL-2 dan IL-4 dalam fibroblas yang diperlukan dalam pembiakan sel. Metode ini dilakukan pada percobaan klinik untuk pengobatan kanker payudara, kanker melanoma, colorectal, dan kanker ginjal. Fibroblas yang menghasilkan IL-2 dan IL4 kemudian dicampur sel tumor autologous yang sudah diradiasi, selanjutnya diinjeksi secara subkutan. Pada percobaan ini diharapkan produksi dan sekresi sitokin lokal fibrosal yang sudah direkayasa genetiknya, akan merangsang respons imun yang kuat terhadap sel tumor yang sudah diradiasi, sehingga terjadi respons imun anti-kanker secara sistemik (Strachan dan Read, 1996).

MEDIKORA Vol. II, No. 1, April 2006: 39 - 56. 


\section{c. Transfer Gen ke TIL}

Salah satu strategi terapi gen untuk kanker yang saat ini banyak diteliti melibatkan modifikasi sel kanker penderita dengan gen yang menyandi sitokin tumor necrosis factor a (TNF-a) ditransfer ke tumor infiltrating lymphocytes (TIL), dengan tujuan untuk meningkatkan aktivitas antitumor yang dimiliki. Metode terapi gen ini dapat dimasukkan pada imunoterapi adoptif, karena gen TNF-a ditreansfer ke TIL untuk meningkatkan aktivitasnya. Populasi TIL adalah alami dari limfosit T di tumor, seperti melanoma metastatik. TNF-a adalah protein alami yang dihasilkan limfosit T, apabila diberikan dalam jumlah banyak paa mencit, dapat merusak tumor. TNF-a adalah suatu senyawa yang besifat toksik dan bila diinfuskan pada manusia akan menimbulkan efek samping yang berrti. Sebagai alternatif digunakan TIL sebagai vektor seluler untuk mentransferkan bahan toksik ini secara langsung ke tumor. Pendekatan trapi gen ini melibatkan transfer gen TNF-a dengan perantaraan retrovirus ke TIL yang diperoleh dari tumor penderita yang dibiakkan dalam biakan sel. Transfusi TIL yang dinsersi dengan gen TNF-a kepada penderita melanoma metastatik, diharapkan TIL tersebut sampai dan berada pada melanoma, mengekspresi TNF-a dan terjadi regresi tumor (Strachan dan Read, 1996).

\section{Metode In Vivo}

Metode in vivo yaitu gen asing yang langsung dimasukkan ke dalam tubuh penderita yang memiliki gen cacat dengan menggunakan suatu vektor. Pendekatan lain yang digunakan terapi gen in vivo adalah suicide genes yang menyandi suatu molekul atau enzim yang mengubah obat dalam keadaan tidak aktif (prodrug) menjadi obat aktif yang dapat membunuh sel tumor. Sel target yang digunakan adalah sel tumor otak glioblastoma multifome. Suicide genes yang ditransferkan ke sel tumor yaitu gen dari berpes simplex virus (HSV) yang menyandi enzim timidin kinase (HSV-tk), memfosforilasi gancyclovir yaitu suatu prodrug menjadi gancyclovir monophosphate di sel yang akan diubah oleh kinase menjadi gancyclovir triphosphate. Senyawa ini menghambat DNA polimerase dan mengakibatkan kematian sel. Terapi ini memiliki keuntungan mengakibatkan by-stander effect, yaitu sel tumor didekatnya yang tidak mempunyai gen HSV-tk juga dapat dirusak. Hal ini kemungkinan disebabkan 
oleh gancyclovir triphosphate yang dihasilkan sel mempunyai gen HSV-tk, yang berdifusi ke sel didekatnya, mungkin melalui gap junction (Strachan dan Read, 1996; Moolten, 1997).

\section{GABUNGAN TERAPI RADIASI DAN TERAPI GEN}

Pengobatan penyakit kanker dengan menggunakan terapi radiasi eksternal terbatas oleh toksisitas dari radiasi jaringan normal dan radioresistensi terhadap dosis radiasi konvensional. Penggunaan radioimunoterapi yang menggunakan antibodi monoklonal dilabel dengan radiaktif untuk mencapai target yaitu tumor yang berhubungan dengan antigen tumor atau reseptor, sehingga hanya sedikit antibodi yang terlokalisasi pada tumor. Terapi gen menawarkan suatu pendekatan untuk mengatasi masalah ini, strategi transfer gen dapat digunakan untuk meningkatkan radiosensitivitas sel kanker, meningkatkan ekspresi antigen atau reseptor pada permukaan sel tumor atau menghasilkan obat toksik atau obat radiosensitising di sel kanker (Stackhouse, Rogers, Buchsbaum, 1999).

Radiasi menimbulkan apoptosis berbagai macam sel tumor. Keseimbangan famili gen anti apoptosis dapat mempertahankan viabilitas sel. Ekspresi yang berlebihan dari gen pro-apoptosis atau gangguan ekspresi dari gen anti-apoptosis menimbulkan peningkatan apoptosis, sehingga meningkatkan kepekaan radiasi seluler (Stackhouse, Rogers, Buchsbaum, 1999).

Mutasi gen DNA repair akan meningkatkan sensivitas sel mamalia terhadap radiasi. Pemusnahan gen DNA repair dengan rekayasa genetika akan meningkatkan kepekaan sel kanker manusia terhadap radiasi. Penghilangan jalur signalling untuk pertumbuhan akan meningkatkan sensitivitas sel tumor terhadap radiasi. Sebagai target potensial adalah famili reseptor epidermal growth factor, termasuk Bcl-2. Kombinasi TNF-a dan radiasi meningkatkan sel tumor, oleh karena pemberian TNF-A sistemik bersifat toksik, maka ekspresi gen TNF-a dilakukan di bawah kontrol promoter EGR-1 yang diinduksi oleh radiasi. Radiasi sel yang gen TNF-a nya dikontrol oleh EGR-1 akan menghasilkan TNF-a yang meningkatkan pembunuhan sel tanpa efek sistemik. Pendekaan ini menunjukkan bahwa terapi gen radiasi dapat digabungkan secara efektif (Stackhouse, Rogers, Buchsbaum, 1999).

Strategi lain dalam penggabungan terapi radiasi dan terapi gen adalah dengan menggunakan vector adenovirus yang menyandi DNA untuk reseptor

MEDIKORA Vol. II, No. 1, April 2006: 39 - 56. 
permukaan sel yang merangsang peningkatan ekspresi reseptor sel tumor. Sel tersebut diberi peptida afinitas tinggi yang dilabel dengan radioaktif, peptida tersebut dapat mengatasi toksisitas sumsum tulang dengan adanya radioimunoterapi, sebab peptida dengan berat molekul rendah lebih cepat dibersihkan dari darah jika dibandingkan antibodi yang dilabel radioaktif. Peptida ini juga dapat menetrasi tumor lebih cepat jika dibandingkan antibodi dan memungkinkan radiaktivitas terdistribusi lebih homogen ke seluruh tumor (Stackhouse, Rogers, Buchsbaum, 1999).

Para peneliti juga berhasil melakukan fusi gen gabungan HSV-tk dan deaminase sitosin E.coli yang ditransduksi ke sel kanker manusia, setelah dimasuki gancyclovir dan 5-FC nampak adanya peningkatan sitotoksik yang diinduksi radiasi (Stackhouse, Rogers, Buchsbaum, 1999).

\section{KESIMPULAN}

Kanker merupakan suatu penyakit degeneratif yang sering menyebabkan kematian apabila tidak mendapat perawatan dengan baik. Terapi kanker yang saat ini dilakukan adalah pembedahan, radioterapi, dan kemoterapi. Terapi tersebut apabila dilakukan sendiri atau bersama-sama, kira-kira dapat menyembuhkan setengah dari penderita kanker. Kemoterapi yang dilakukan pada penderita kanker tidak hanya merusak sel kanker, tetapi juga merusak sel normal yang sedang berproliferasi, seperti misalnya sel hematopoietik dan sel epitel, sehingga dapat menimbulkan efek samping yang membahayakan penderita. Radioterapi juga memiliki keterbatasan dalam pengobatan penyakit kanker hal ini karena dibatasi oleh soksisitas dari radiasi pada sel normal dan resistensi dari banyak jenis keganasan terhadap dosis radiasi konvnesional.

Oleh karena terapi konvensional yang dilakukan pada penderita kanker belum memberikan hasil yang memuaskan, saat ini dicoba berbagai macam pendekatan baru terapi kanker. Tiga targetmolekuler baru yang saat ini merupakan target dari pengobatan penyakit kanker adalah onkogen, tumor suppressor genes, serta gen pengatur replikasi DNA dan DNA repair. Obat genetik baru yang dipakai untuk terapi kanker adalah antisense agent dan triples agent.

Terapi gen untuk kanker dapat dilakukan secara ex vivo dan in vivo. Terapi gen ex vivo dilakukan dengan cara modefikasi genetik sel tumor, modifikasi genetik fibroblas, dan transfer gen kepada tumor-infiltrating lymphocytes (TIL). Terapi 
gen in vivo dilakukan dengan cara meningkatkan imunogenesitas sel tumor atau menginsersikan suicide genes pada sel tumor. Selanajutnya endekatan baru terapi kanker juga dilakukan dengan kombinasi terapi gen dan terapi radiasi, onkolisis dengan perantaraan virus atau dengan cara merusak pembuluh darah tumor yang dibutuhkan untuk pertumbuhan dan penyebaran tumor.

Dengan adanya pendekatan baru dalam terapi kanker, diharapkan dapat dilakukan pengobatan penderita penyakit kanker dengan hasil yang lebih baik serta tidak menimbulkan efek samping yang berarti bagi penderita.

\section{DAFTAR PUSTAKA}

Blaese, R.M. (1997). Gene Therapy for Cancer. Sci. Am. June, 91 - 95.

Cohen, J.S. Hogan, M.E. (1994). The New Genetic Medicines. Sci. Am. Dec., 76 - 82.

Folkman, J. (1996). Fighting Cancer by Attacking its Blood Supply. Sci. Am. Sep., 116 - 119.

Moolten, F.L. (1997). Suicide Genes for Cancer Therapy, Sci. Med., Jul/Aug., 16 - 25.

Oliff, A., Gibbs, J.B. McCormick, F. (1996). New Molecular Targets for Cancer Therapy, Sci. Am. 110 - 115 .

Rosenberg, S.A. (1990). Adoptive Immunotherapy for Cancer, Sci. Am. May., 62 - 69.

Stackhouse, M.A. Rogers, B.E., Buchsbaum, D.J. (1999). Radiation Therapy and Gene Therapy, Sci. Med. March/April, 4 - 5.

Strachan, T., Read, A.P. (1996). Human Molecular Genetics, Bios. Scient. Publ. \& John Wiley \& Sons, Canada \& USA, 580 - 583.

Williams, N. (1996). An Immune Boost to the War on Cancer, Science 272: 28-30.

MEDIKORA Vol. II, No. 1, April 2006: 39-56. 